\title{
Kribbia dieselivorans gen. nov., sp. nov., a novel member of the family Intrasporangiaceae
}

\author{
Seo-Youn Jung, Hee-Sik Kim, Jae Jun Song, Seung-Goo Lee, \\ Tae-Kwang Oh and Jung-Hoon Yoon \\ Korea Research Institute of Bioscience and Biotechnology (KRIBB), PO Box 115, Yusong, \\ Taejon, South Korea
}

Correspondence

Jung-Hoon Yoon

jhyoon@kribb.re.kr

\begin{abstract}
Two Gram-positive, catalase-positive, irregular short rod- or coccoid-shaped bacterial strains, $\mathrm{N} 113^{\top}$ and $\mathrm{R} 33$, were isolated from an enrichment culture with diesel oil-degradation activity and their taxonomic positions were investigated using a polyphasic approach. Phenotypic, phylogenetic and genetic similarities indicated that strains $\mathrm{N}_{113^{\top}}$ and $\mathrm{R} 33$ were representatives of the same species. Phylogenetic analysis based on $16 \mathrm{~S}$ rRNA gene sequences showed that strains $\mathrm{N}_{113}{ }^{\top}$ and R33 form a lineage independent from those of members of the family Intrasporangiaceae. The novel isolates had cell-wall peptidoglycan based on meso-diaminopimelic acid, $\mathrm{MK}-8\left(\mathrm{H}_{4}\right)$ as the predominant menaquinone and 10 -methyl- $\mathrm{C}_{18: 0}$, iso- $\mathrm{C}_{16: 0}, \mathrm{C}_{18: 1} \omega 9 c, \mathrm{C}_{16: 0}$ and $\mathrm{C}_{18: 0}$ as the major cellular fatty acids. The DNA G $+\mathrm{C}$ contents were $69 \cdot 6-69 \cdot 9 \mathrm{~mol} \%$. These chemotaxonomic properties, together with phylogenetic distinctiveness, distinguish the two novel strains from recognized members of the family Intrasporangiaceae. On the basis of phenotypic, phylogenetic and genetic data, strains $\mathrm{N}_{113^{\top}}\left(=\mathrm{KCTC} 19143^{\top}=\mathrm{JCM} 13585^{\top}\right)$ and R33 are classified as representatives of a novel genus and species, Kribbia dieselivorans gen. nov., sp. nov., within the family Intrasporangiaceae.
\end{abstract}

The family Intrasporangiaceae was proposed as a family of the suborder Micrococcineae by Stackebrandt et al. (1997) on the basis of $16 \mathrm{~S}$ rRNA gene sequence analysis and the family currently consists of 11 genera. The family Intrasporangiaceae is a phenotypically heterogeneous taxon which can be divided into three groups on the basis of the diagnostic diamino acid in the cell-wall peptidoglycan. The genera Intrasporangium (Kalakoutskii et al., 1967), Terrabacter (Collins et al., 1989), Terracoccus (Prauser et al., 1997) and Arsenicicoccus (Collins et al., 2004) contain LLdiaminopimelic acid, the genera Janibacter (Martin et al., 1997), Tetrasphaera (Maszenan et al., 2000), Knoellia (Groth et al., 2002) and Oryzihumus (Kageyama et al., 2005) contain meso-diaminopimelic acid and the genera Ornithinicoccus (Groth et al., 1999), Ornithinimicrobium (Groth et al., 2001) and Serinicoccus (Yi et al., 2004) contain L-ornithine. In this study, we describe two meso-diaminopimelic acid-containing bacterial strains, $\mathrm{N} 113^{\mathrm{T}}$ and $\mathrm{R} 33$, which are phylogenetically related to the family Intrasporangiaceae. The aim of the present study was to determine the exact taxonomic

Abbreviation: FAME, fatty acid methyl ester.

The GenBank/EMBL/DDBJ accession numbers for the 16S rRNA

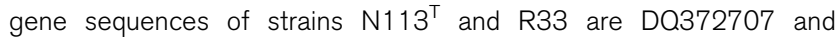
D0062659, respectively.

A supplementary table detailing the cellular fatty acid contents of Kribbia dieselivorans sp. nov. strains $\mathrm{N}_{113}{ }^{\top}$ and $\mathrm{R} 33$ is available in IJSEM Online. position of strains $\mathrm{N} 113^{\mathrm{T}}$ and $\mathrm{R} 33$ using a polyphasic approach that included analysis of phenotypic properties, detailed phylogenetic analysis based on 16S rRNA gene sequences and genetic relatedness.

Tidal flat sediment collected from Kwangyang, Korea, was used as the source for the isolation of diesel oil-degrading bacteria. Strains $\mathrm{N}_{11}{ }^{\mathrm{T}}$ and R33 were isolated from an enrichment culture with diesel oil-degradation activity by dilution plating on $10 \times$ diluted nutrient agar (Difco) and R2A agar (Difco), respectively. To investigate their morphological, physiological and biochemical characteristics, strains $\mathrm{N}_{11} 3^{\mathrm{T}}$ and $\mathrm{R} 33$ were routinely cultivated at $30^{\circ} \mathrm{C}$ on trypticase soy agar (TSA; Difco). Growth at various temperatures from 4 to $50{ }^{\circ} \mathrm{C}$ was measured on TSA. The $\mathrm{pH}$ range for growth was determined in nutrient broth (NB; Difco) that was adjusted to various $\mathrm{pH}$ values (initial $\mathrm{pH} 4 \cdot 5-11.5$ at intervals of $0.5 \mathrm{pH}$ units). Growth under anaerobic conditions was determined after incubation in an anaerobic chamber on TSA and on TSA supplemented with nitrate, both of which had been prepared anaerobically using nitrogen. Cell morphology and presence of flagella were examined by light microscopy (E600; Nikon) and transmission electron microscopy by using cells grown on TSA. Gram reaction was determined by using the bioMérieux Gram stain kit according to the manufacturer's instructions. Catalase and oxidase activities and hydrolysis of casein, hypoxanthine, tyrosine, xanthine, starch and 
Tweens 20, 40, 60 and 80 were determined as described by Cowan \& Steel (1965). Hydrolysis of aesculin, gelatin and urea and nitrate reduction were studied as described previously (Lanyi, 1987). Acid production from carbohydrates was determined according to Leifson (1963). Utilization of various substrates for growth was tested as described by Yurkov et al. (1994). The API ZYM system (bioMérieux) was used to determine enzyme activity. Other physiological and biochemical tests were performed with the API 20E and API 20NE systems (bioMérieux). Antibiotic sensitivity was tested by spreading bacterial suspension on TSA and applying discs impregnated with the following antibiotics (concentration per disc); ampicillin $(10 \mu \mathrm{g})$, carbenicillin $(100 \mu \mathrm{g})$, cephalothin $(30 \mu \mathrm{g})$, chloramphenicol $(100 \mu \mathrm{g})$, gentamicin $(30 \mu \mathrm{g})$, lincomycin $(15 \mu \mathrm{g})$, kanamycin $(30 \mu \mathrm{g})$, neomycin $(30 \mu \mathrm{g})$, novobiocin $(5 \mu \mathrm{g})$, oleandomycin $(15 \mu \mathrm{g})$, penicillin $\mathrm{G}(20 \mathrm{U})$, polymyxin B $(100 \mathrm{U})$, streptomycin $(50 \mu \mathrm{g})$ and tetracycline $(30 \mu \mathrm{g})$.

Strains $\mathrm{N} 113^{\mathrm{T}}$ and $\mathrm{R} 33$ were cultivated for 3 days in trypticase soy broth (Difco) at $30^{\circ} \mathrm{C}$ to obtain the cell mass required for isoprenoid quinone and cell wall analyses and DNA extraction. Isoprenoid quinones were analysed as described previously (Komagata \& Suzuki, 1987) using reverse-phase HPLC. The isomer type of the cell-wall diamino acid was analysed according to the method of Komagata \& Suzuki (1987). For fatty acid methyl ester (FAME) analysis, cell mass of strains $\mathrm{N}_{11} 3^{\mathrm{T}}$ and $\mathrm{R} 33$ was harvested from TSA plates after cultivation for 3 days at $30{ }^{\circ} \mathrm{C}$. FAMEs were extracted and prepared according to the standard protocol of the MIDI/Hewlett Packard Microbial Identification System (Sasser, 1990). Chromosomal DNA was extracted and purified by the procedure described previously (Yoon et al., 1996). The DNA G + C content was determined by the method of Tamaoka \& Komagata (1984) with a modification that DNA was hydrolysed and the resultant nucleotides were analysed by reverse-phase HPLC. The $16 \mathrm{~S}$ rRNA gene amplification was performed according to the method of Yoon et al. (1998) using two universal primers. Sequencing of the amplified 16S rRNA gene was performed as described by Yoon et al. (2003). Alignment of sequences was carried out with CLUSTAL W (Thompson et al., 1994) and gaps at the $5^{\prime}$ and $3^{\prime}$ ends of the alignment were omitted from further analysis. The evolutionary distances were calculated using the Kimura two-parameter correction with the CLUSTAL W package (Thompson et al., 1994). A phylogenetic tree was constructed by using the neighbourjoining method (Saitou \& Nei, 1987) on the basis of distance matrix data. The reliability of the grouping was assessed by 1000 bootstrap resamplings of the neighbour-joining dataset by using the CLUSTAL $\mathrm{W}$ package. DNA-DNA hybridization was determined by the microplate hybridization method (Ezaki et al., 1989) using photobiotin-labelled DNA probes.

Morphological, cultural, physiological and biochemical characteristics of strains $\mathrm{N} 113^{\mathrm{T}}$ and $\mathrm{R} 33$ are given in the genus and species descriptions (see below) or shown in
Table 1. Strains $\mathrm{N} 113^{\mathrm{T}}$ and R33 had meso-diaminopimelic acid as the diagnostic diamino acid in the cell-wall peptidoglycan. They contained MK- $8\left(\mathrm{H}_{4}\right)$ as the predominant menaquinone. Strains $\mathrm{N} 113^{\mathrm{T}}$ and R33 had cellular fatty acid profiles that contained large amounts of straight-chain, branched, unsaturated and 10-methyl fatty acids. The major components ( $>10 \%$ of total fatty acids) were 10 methyl- $\mathrm{C}_{18: 0}$, iso- $\mathrm{C}_{16: 0}, \mathrm{C}_{18: 1} \omega 9 c, \mathrm{C}_{16: 0}$ and $\mathrm{C}_{18: 0}$ (see Supplementary Table S1 in IJSEM Online). The DNA G + C contents of strains $\mathrm{N}_{11} 3^{\mathrm{T}}$ and R33 were 69.9 and $69 \cdot 6 \mathrm{~mol} \%$, respectively. The $16 \mathrm{~S}$ rRNA gene sequences of strains $\mathrm{N} 113^{\mathrm{T}}$ and $\mathrm{R} 33$ determined in this study each comprised 1476 nucleotides and were $99.9 \%$ similar (one nucleotide difference). Comparative 16S rRNA gene sequence analyses revealed that strains $\mathrm{N} 113^{\mathrm{T}}$ and $\mathrm{R} 33$ were phylogenetically most closely related to the family Intrasporangiaceae. In a phylogenetic tree based on the neighbour-joining algorithm, strains $\mathrm{N} 113^{\mathrm{T}}$ and $\mathrm{R} 33$ formed a distinct phylogenetic lineage within the family Intrasporangiaceae (Fig. 1). 16S rRNA gene sequence similarity values between strains $\mathrm{N}_{11} 3^{\mathrm{T}}$ and $\mathrm{R} 33$ and genera within the family Intrasporangiaceae were as follows: Janibacter (95.3-96.0 \%), Intrasporangium (95.6\%), Terracoccus $(95 \cdot 6 \%)$, Terrabacter $(95 \cdot 7-95 \cdot 9 \%)$, Arsenicicoccus (95.5\%), Knoellia (94.9-95.0\%), Ornithinicoccus $(94 \cdot 8 \%)$, Ornithinimicrobium (94.3\%), Oryzihumus (94.2\%), Serinicoccus $(94 \cdot 2 \%)$ and Tetrasphaera (93.8-94.5\%). Strains $\mathrm{N} 113^{\mathrm{T}}$ and R33 exhibited a mean DNA-DNA relatedness value of $90 \%$ when their DNAs were used individually as labelled DNA probes for cross-hybridization, indicating that the two strains are members of the same genomic species (Wayne et al., 1987). In view of their phenotypic, phylogenetic and genetic similarities, strains $\mathrm{N} 113^{\mathrm{T}}$ and $\mathrm{R} 33$ are representatives of the same species.

Strains $\mathrm{N} 113^{\mathrm{T}}$ and R33 could be clearly distinguished from recognized members of the family Intrasporangiaceae by differences in chemotaxonomic properties, particularly by the diamino acid type in position 3 of the peptidoglycan and by fatty acid profiles (Table 1 ). Strains $\mathrm{N} 113^{\mathrm{T}}$ and $\mathrm{R} 33$ are distinguishable from the genera which contain LL-diaminopimelic acid or L-ornithine as the diagnostic diamino acid (Table 1). The fatty acid profiles, particularly the major fatty acids, distinguish strains $\mathrm{N} 113^{\mathrm{T}}$ and $\mathrm{R} 33$ from recognized genera of the family Intrasporangiaceae, although there may be differences in the proportions of some fatty acids probably due to differences in cultivation conditions and extraction procedures (Table 1 ). The iso- $\mathrm{C}_{15: 0}$ fatty acid was a minor component in strains $\mathrm{N} 113^{\mathrm{T}}$ and $\mathrm{R} 33$, whereas it was a major component in all genera of the family Intrasporangiaceae, except the genus Janibacter. The 10methyl fatty acids were major fatty acids in strains $\mathrm{N} 113^{\mathrm{T}}$ and R33, but they were absent or present as minor components in other genera of the family Intrasporangiaceae. On the basis of the phylogenetic data and differential chemotaxonomic properties reported here, it is suggested that strains $\mathrm{N} 113^{\mathrm{T}}$ and $\mathrm{R} 33$ represent a new genus 
Table 1. Differential characteristics of Kribbia dieselivorans gen. nov., sp. nov. and genera of the family Intrasporangiaceae

Genera: 1, Kribbia; 2, Arsenicicoccus (data from Collins et al., 2004); 3, Ornithinimicrobium (Groth et al., 2001); 4, Serinicoccus (Yi et al., 2004); 5, Janibacter (Martin et al., 1997; Imamura et al., 2000; Yoon et al., 2000, 2004; Kämpfer et al., 2006); 6, Knoellia (Groth et al., 2002); 7, Tetrasphaera (Maszenan et al., 2000; Hanada et al., 2002); 8, Ornithinicoccus (Groth et al., 1999); 9, Oryzihumus (Kageyama et al., 2005); 10, Intrasporangium (Kalakoutskii et al., 1967; Schumann et al., 1997; Groth et al., 2001); 11, Terracoccus (Prauser et al., 1997); 12, Terrabacter (Collins et al., 1989; Montero-Barrientos et al., 2005). L-Orn, L-ornithine; meso- $\mathrm{A}_{2} \mathrm{pm}$, meso-diaminopimelic acid; LL- $\mathrm{A}_{2} \mathrm{pm}$, LL-diaminopimelic acid.

\begin{tabular}{|c|c|c|c|c|c|c|c|c|c|c|c|c|}
\hline Characteristic & 1 & 2 & 3 & 4 & 5 & 6 & 7 & 8 & 9 & 10 & 11 & 12 \\
\hline Cell morphology & $\begin{array}{l}\text { Irregular short } \\
\text { rods or cocci }\end{array}$ & Cocci & $\begin{array}{l}\text { Irregular rods } \\
\text { and cocci }\end{array}$ & Cocci & $\begin{array}{l}\text { Coccoid to } \\
\text { rod-shaped }\end{array}$ & $\begin{array}{l}\text { Irregular rods } \\
\text { and cocci }\end{array}$ & $\begin{array}{l}\text { Cocci or } \\
\text { short rods }\end{array}$ & Cocci & Irregular rods & Hyphae & Cocci & $\begin{array}{l}\text { Irregular } \\
\text { rods }\end{array}$ \\
\hline $\begin{array}{l}\text { Cell wall } \\
\text { diamino acid }\end{array}$ & meso- $\mathrm{A}_{2} \mathrm{pm}$ & LL- $\mathrm{A}_{2} \mathrm{pm}$ & L-Orn & L-Orn & meso- $\mathrm{A}_{2} \mathrm{pm}$ & meso- $\mathrm{A}_{2} \mathrm{pm}$ & meso- $\mathrm{A}_{2} \mathrm{pm}$ & L-Orn & meso- $\mathrm{A}_{2} \mathrm{pm}$ & LL- $\mathrm{A}_{2} \mathrm{pm}$ & LL- $\mathrm{A}_{2} \mathrm{pm}$ & LL- $\mathrm{A}_{2} \mathrm{pm}$ \\
\hline $\begin{array}{l}\text { Major } \\
\text { menaquinone }\end{array}$ & MK- $8\left(\mathrm{H}_{4}\right)$ & MK-8 $\left(\mathrm{H}_{4}\right)$ & MK-8 $\left(\mathrm{H}_{4}\right)$ & MK-8 $\left(\mathrm{H}_{4}\right)$ & MK- $8\left(\mathrm{H}_{4}\right)$ & MK-8 $\left(\mathrm{H}_{4}\right)$ & MK-8 $\left(\mathrm{H}_{4}\right)$ & MK- $8\left(\mathrm{H}_{4}\right)$ & MK- $8\left(\mathrm{H}_{4}\right)$ & MK-8 & MK- $8\left(\mathrm{H}_{4}\right)$ & MK-8 $\left(\mathrm{H}_{4}\right)$ \\
\hline $\begin{array}{l}\text { Major fatty acid } \\
(>10 \% \text { of } \\
\text { total fatty } \\
\text { acids) }\end{array}$ & $\begin{array}{c}\text { 10-methyl- } \mathrm{C}_{18: 0}, \\
\text { iso- } \mathrm{C}_{16: 0} \\
\mathrm{C}_{18: 1} \omega 9 \mathrm{c} \\
\mathrm{C}_{16: 0}, \mathrm{C}_{18: 0}\end{array}$ & $\begin{array}{l}\mathrm{C}_{16: 1} \omega 7 c, \\
\text { iso- } \mathrm{C}_{15: 0} \\
\mathrm{C}_{18: 1} \omega 9 c \\
\text { anteiso- } \mathrm{C}_{15: 0}\end{array}$ & $\begin{array}{l}\text { iso- } \mathrm{C}_{16: 0} \\
\text { iso- } \mathrm{C}_{15: 0} \\
\text { anteiso- } \mathrm{C}_{15: 0}\end{array}$ & $\begin{array}{l}\text { iso- } C_{15: 0}, \\
\text { iso- } C_{16: 0} \\
\text { iso- } C_{17: 1} \omega 9 c\end{array}$ & $\begin{array}{c}\text { iso- } \mathrm{C}_{16: 0} \\
\mathrm{C}_{17: 1} \omega 8 c \\
\mathrm{C}_{18: 1} \omega 9 c \\
\mathrm{C}_{17: 0}\end{array}$ & $\begin{array}{l}\text { iso- } \mathrm{C}_{15: 0}, \\
\text { iso- } \mathrm{C}_{17: 0} \\
\text { iso- } \mathrm{C}_{16: 0} \\
\text { anteiso- } \mathrm{C}_{17: 0}\end{array}$ & $\begin{array}{l}\text { (anteiso- } \mathrm{C}_{15: 0}, \\
\left.\text { iso- } \mathrm{C}_{15: 0}\right)^{*} \\
\text { or (iso- } \mathrm{C}_{16: 0}, \\
\text { anteiso- } \mathrm{C}_{17: 0}, \\
\left.\text { iso- } \mathrm{C}_{15: 0}\right) \dagger \text { or } \\
\quad\left(\text { iso- } \mathrm{C}_{16: 0},\right. \\
\text { anteiso- } \mathrm{C}_{17: 0} \text { ) }\end{array}$ & $\begin{array}{l}\text { iso- } \mathrm{C}_{15: 0} \\
\text { anteiso- } \mathrm{C}_{15: 0}\end{array}$ & $\begin{array}{l}\text { iso- } \mathrm{C}_{16: 0} \text {, } \\
\text { iso- } \mathrm{C}_{15: 0} \text {, } \\
\text { iso- } \mathrm{C}_{14: 0}\end{array}$ & $\begin{array}{l}\text { iso- } \mathrm{C}_{15: 0} \\
\text { anteiso- } \mathrm{C}_{15: 0} \\
\text { iso- } \mathrm{C}_{16: 0}\end{array}$ & $\begin{array}{l}\text { iso- } \mathrm{C}_{15: 0} \\
\text { anteiso- } \mathrm{C}_{15: 0} \\
\mathrm{C}_{16: 0}\end{array}$ & $\begin{array}{c}\text { (iso- } \mathrm{C}_{15: 0}, \\
\left.\text { anteiso- } \mathrm{C}_{15: 0}\right) \S \text { or } \\
\left(\text { iso- } \mathrm{C}_{15: 0},\right. \\
\text { iso- } \mathrm{C}_{14: 0}, \\
\left.\text { iso- } \mathrm{C}_{16: 0}\right) \|\end{array}$ \\
\hline $\begin{array}{l}\text { DNA G+C } \\
(\mathrm{mol} \%)\end{array}$ & $69-70$ & $72 \cdot 2$ & 70 & 72 & $69-73$ & $68-69$ & $68-71$ & 72 & $72-73$ & $68 \cdot 2$ & 73 & $69 \cdot 8-72 \cdot 4$ \\
\hline
\end{tabular}

Data for ${ }^{\star}$ Tetrasphaera elongata, $\dagger$ Tetrasphaera australiensis, $\ddagger$ Tetrasphaera japonica, $₫$ Terrabacter terrae and ॥Terrabacter tumescens. 


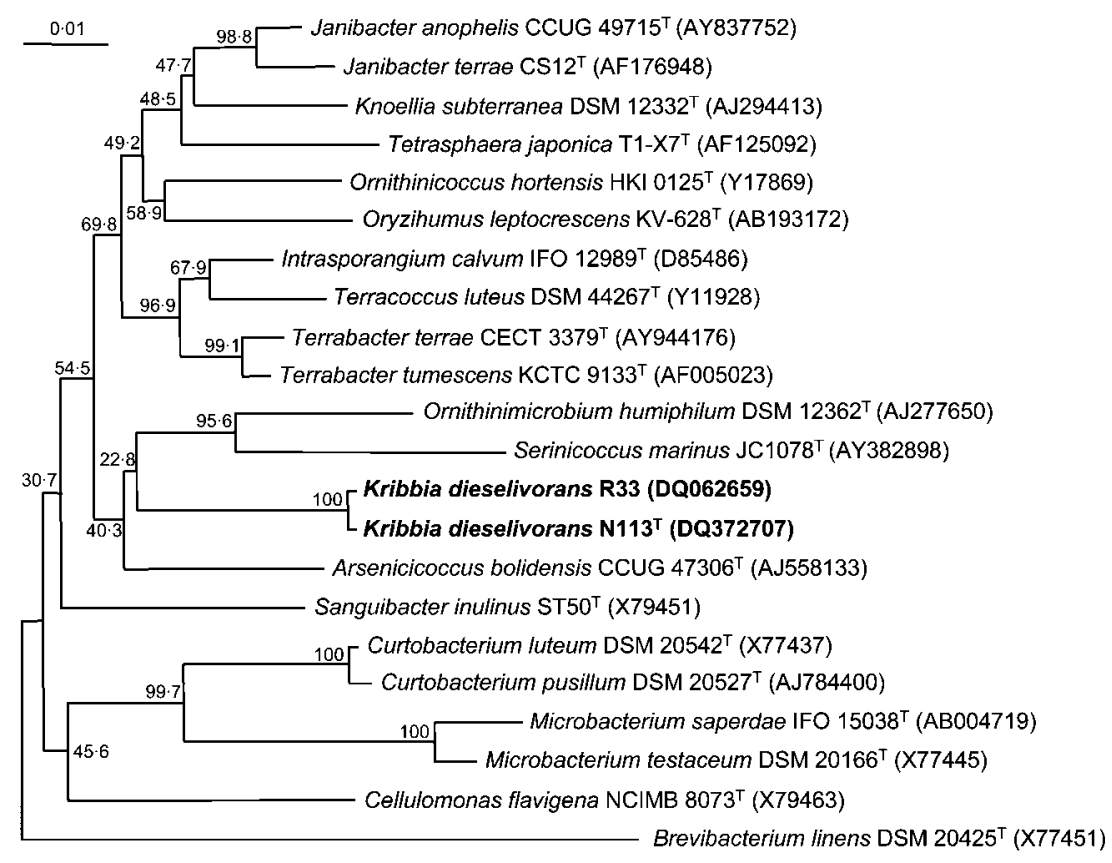

Fig. 1. Neighbour-joining tree based on 16S rRNA gene sequences showing the phylogenetic positions of Kribbia dieselivorans gen. nov., sp. nov. and some other related taxa. Bar, 0.01 substitutions per nucleotide position. and novel species within the family Intrasporangiaceae, for which the name Kribbia dieselivorans gen. nov., sp. nov. is proposed.

\section{Description of Kribbia gen. nov.}

Kribbia (Kribb.i'a. N.L. fem. n. Kribbia arbitrary name formed from the acronym of the Korea Research Institute of Bioscience and Biotechnology, KRIBB, where taxonomic studies of this taxon were performed).

Cells are Gram-positive, non-flagellated, irregular short rods or cocci. The cell-wall peptidoglycan contains mesodiaminopimelic acid. The predominant menaquinone is MK-8 $\left(\mathrm{H}_{4}\right)$. Major cellular fatty acids ( $>10 \%$ of total fatty acids) are 10-methyl- $\mathrm{C}_{18: 0}$, iso- $\mathrm{C}_{16: 0}, \mathrm{C}_{18: 1} \omega 9 c, \mathrm{C}_{16: 0}$ and $\mathrm{C}_{18: 0}$. The DNA $\mathrm{G}+\mathrm{C}$ content is $69-70 \mathrm{~mol} \%$. Phylogenetically, the genus is a member of the family Intrasporangiaceae within the suborder Micrococcineae of the order Actinomycetales. The type species is Kribbia dieselivorans.

\section{Description of Kribbia dieselivorans sp. nov.}

Kribbia dieselivorans (die.se.li.vo'rans. N.L. n. dieselum diesel; L. v. vorare to devour; N.L. part. adj. dieselivorans diesel oil-devouring).

Exhibits the following properties in addition to those given in the genus description. Cells are 0.4-0.6 $\times 1 \cdot 0-1.5 \mu \mathrm{m}$. Catalase-positive, oxidase-negative and urease-negative. Growth occurs between 8 and $42{ }^{\circ} \mathrm{C}$ with an optimum temperature of $30^{\circ} \mathrm{C}$. Optimal $\mathrm{pH}$ for growth is $6 \cdot 5-7 \cdot 5$. Anaerobic growth occurs on TSA and on TSA with nitrate.
Casein, gelatin, aesculin and Tweens 20, 40, 60 and 80 are hydrolysed, but starch, hypoxanthine, xanthine and tyrosine are not. Arginine dihydrolase, lysine decarboxylase and ornithine decarboxylase are absent. $\mathrm{H}_{2} \mathrm{~S}$ and indole are not produced. Nitrate is reduced to nitrite. Acetate, benzoate, Dcellobiose and pyruvate are utilized as sole carbon and energy sources; D-glucose, D-trehalose, sucrose and maltose are weakly utilized. D-Fructose, D-galactose, D-mannose, Dxylose, L-arabinose, citrate, formate, salicin, succinate, Lglutamate and L-malate are not utilized. Acid is produced from D-glucose, D-cellobiose, sucrose, maltose and Dtrehalose, but not from D-sorbitol, myo-inositol, D-ribose, D-fructose, D-mannitol, melibiose, L-arabinose, D-melezitose, D-galactose, L-rhamnose, lactose or D-raffinose. Susceptible to streptomycin, penicillin G, chloramphenicol, ampicillin, cephalothin, gentamicin, novobiocin, tetracycline, lincomycin, oleandomycin, neomycin and carbenicillin, but not to polymyxin B or kanamycin. In assays with the API ZYM system (bioMérieux), esterase (C4), esterase lipase (C8), leucine arylamidase, naphthol-AS-BIphosphohydrolase, $\beta$-galactosidase, $\alpha$-glucosidase and $\beta$ glucosidase are present, but alkaline phosphatase, lipase (C14), valine arylamidase, cystine arylamidase, trypsin, $\alpha$ chymotrypsin, acid phosphatase, $\alpha$-galactosidase, $\beta$-glucuronidase, $N$-acetyl- $\beta$-glucosaminidase, $\alpha$-mannosidase and $\alpha$-fucosidase are absent. The major cellular fatty acids ( $>10 \%$ of total fatty acids) are 10-methyl- $\mathrm{C}_{18: 0}$, iso- $_{16: 0}$, $\mathrm{C}_{18: 1} \omega 9 c, \mathrm{C}_{16: 0}$ and $\mathrm{C}_{18: 0}$. The DNA $\mathrm{G}+\mathrm{C}$ content is 69.6-69.9 $\mathrm{mol} \%$.

The type strain, $\mathrm{N} 113^{\mathrm{T}}\left(=\mathrm{KCTC} 19143^{\mathrm{T}}=\mathrm{JCM} 13585^{\mathrm{T}}\right.$ ), was isolated from tidal flat sediment from Kwangyang, Korea. 


\section{Note added in proof}

Another new genus has been described in the Intrasporangiaceae with the same diagnostic diamino acid, Phycicoccus jejuensis (see Lee, 2006, this issue IJSEM, pp. 2369-2373).

\section{Acknowledgements}

This work was supported by the Eco-technopia 21 project of the Ministry of Environment and the 21C Frontier Program of Microbial Genomics and Applications (grant MG05-0401-2-0) from the Ministry of Science and Technology (MOST) of the Republic of Korea.

\section{References}

Collins, M. D., Dorsch, M. \& Stackebrandt, E. (1989). Transfer of Pimelobacter tumescens to Terrabacter gen. nov. as Terrabacter tumescens comb. nov. and of Pimelobacter jensenii to Nocardioides as Nocardioides jensenii comb. nov. Int J Syst Bacteriol 39, 1-6.

Collins, M. D., Routh, J., Saraswathy, A., Lawson, P. A., Schumann, P., Welinder-Olsson, C. \& Falsen, E. (2004). Arsenicicoccus bolidensis gen. nov., sp. nov., a novel actinomycete isolated from contaminated lake sediment. Int J Syst Evol Microbiol 54, 605-608.

Cowan, S. T. \& Steel, K. J. (1965). Manual for the Identification of Medical Bacteria. London: Cambridge University Press.

Ezaki, T., Hashimoto, Y. \& Yabuuchi, E. (1989). Fluorometric deoxyribonucleic acid-deoxyribonucleic acid hybridization in microdilution wells as an alternative to membrane filter hybridization in which radioisotopes are used to determine genetic relatedness among bacterial strains. Int J Syst Bacteriol 39, 224-229.

Groth, I., Schumann, P., Martin, K., Schuetze, B., Augsten, K., Kramer, I. \& Stackebrandt, E. (1999). Ornithinicoccus hortensis gen. nov., sp. nov., a soil actinomycete which contains L-ornithine. Int J Syst Bacteriol 49, 1717-1724.

Groth, I., Schumann, P., Weiss, N., Schuetze, B., Augsten, K. \& Stackebrandt, E. (2001). Ornithinimicrobium humiphilum gen. nov., sp. nov., a novel soil actinomycete with L-ornithine in the peptidoglycan. Int J Syst Evol Microbiol 51, 81-87.

Groth, I., Schumann, P., Schutze, B., Augsten, K. \& Stackebrandt, E. (2002). Knoellia sinensis gen. nov., sp. nov. and Knoellia subterranea sp. nov., two novel actinobacteria isolated from a cave. Int J Syst Evol Microbiol 52, 77-84.

Hanada, S., Liu, W.-T., Shintani, T., Kamagata, Y. \& Nakamura, K. (2002). Tetrasphaera elongata sp. nov., a polyphosphate-accumulating bacterium isolated from activated sludge. Int J Syst Evol Microbiol 52, 883-887.

Imamura, Y., Ikeda, M., Yoshida, S. \& Kuraishi, H. (2000). Janibacter brevis sp. nov., a new trichloroethylene-degrading bacterium isolated from polluted environments. Int J Syst Evol Microbiol 50, 1899-1903.

Kageyama, K., Takahashi, Y., Seki, T., Tomoda, H. \& Ōmura, S. (2005). Oryzihumus leptocrescens gen. nov., sp. nov. Int J Syst Evol Microbiol 55, 2555-2559.

Kalakoutskii, L. V., Kirillova, I. P. \& Krasil'nikov, N. A. (1967). A new genus of the Actinomycetales, Intrasporangium gen. nov. J Gen Microbiol 48, 79-85.

Kämpfer, P., Terenius, O., Lindh, J. M. \& Faye, I. (2006). Janibacter anophelis sp. nov., isolated from the midgut of Anopheles arabiensis. Int J Syst Evol Microbiol 56, 389-392.

Komagata, K. \& Suzuki, K. (1987). Lipids and cell-wall analysis in bacterial systematics. Methods Microbiol 19, 161-207.
Lanyi, B. (1987). Classical and rapid identification methods for medically important bacteria. Methods Microbiol 19, 1-67.

Leifson, E. (1963). Determination of carbohydrate metabolism of marine bacteria. J Bacteriol 85, 1183-1184.

Martin, K., Schumann, P., Rainey, F. A., Schuetze, B. \& Groth, I. (1997). Janibacter limosus gen. nov., sp. nov., a new actinomycete with meso-diaminopimelic acid in the cell wall. Int J Syst Bacteriol 47, 529-534.

Maszenan, A. M., Seviour, R. J., Patel, B. K. C., Schumann, P., Burghardt, J., Tokiwa, Y. \& Stratton, H. M. (2000). Three isolates of novel polyphosphate-accumulating Gram-positive cocci, obtained from activated sludge, belong to a new genus, Tetrasphaera gen. nov., and description of two new species, Tetrasphaera japonica sp. nov. and Tetrasphaera australiensis sp. nov. Int J Syst Evol Microbiol 50, 593-603.

Montero-Barrientos, M., Rivas, R., Velázquez, E., Monte, E. \& Roig, M. G. (2005). Terrabacter terrae sp. nov., a novel actinomycete isolated from soil in Spain. Int J Syst Evol Microbiol 55, 2491-2495.

Prauser, H., Schumann, P., Rainey, F. A., Kroppenstedt, R. M. \& Stackebrandt, E. (1997). Terracoccus luteus gen. nov., sp. nov., an LL-diaminopimelic acid-containing coccoid actinomycete from soil. Int J Syst Bacteriol 47, 1218-1224.

Saitou, N. \& Nei, M. (1987). The neighbor-joining method: a new method for reconstructing phylogenetic trees. Mol Biol Evol 4, 406425.

Sasser, M. (1990). Identification of bacteria by gas chromatography of cellular fatty acids, MIDI Technical Note 101. Newark, DE: MIDI Inc.

Schumann, P., Prauser, H., Rainey, F. A., Stackebrandt, E. \& Hirsch, P. (1997). Friedmanniella antarctica gen. nov., sp. nov., an LLdiaminopimelic acid-containing actinomycete from Antarctic sandstone. Int J Syst Bacteriol 47, 278-283.

Stackebrandt, E., Rainey, F. A. \& Ward-Rainey, N. L. (1997). Proposal for a new hierarchic classification system, Actinobacteria classis nov. Int J Syst Bacteriol 47, 479-491.

Tamaoka, J. \& Komagata, K. (1984). Determination of DNA base composition by reversed-phase high-performance liquid chromatography. FEMS Microbiol Lett 25, 125-128.

Thompson, J. D., Higgins, D. G. \& Gibson, T. J. (1994). CLUSTAL W: improving the sensitivity of progressive multiple sequence alignment through sequence weighting, position-specific gap penalties and weight matrix choice. Nucleic Acids Res 22, 4673-4680.

Wayne, L. G., Brenner, D. J., Colwell, R. R. \& 9 other authors (1987). International Committee on Systematic Bacteriology. Report of the ad hoc committee on reconciliation of approaches to bacterial systematics. Int J Syst Bacteriol 37, 463-464.

Yi, H., Schumann, P., Sohn, K. \& Chun, J. (2004). Serinicoccus marinus gen. nov., sp. nov., a novel actinomycete with L-ornithine and L-serine in the peptidoglycan. Int J Syst Evol Microbiol 54, 15851589.

Yoon, J.-H., Kim, H., Kim, S.-B., Kim, H.-J., Kim, W. Y., Lee, S. T., Goodfellow, M. \& Park, Y.-H. (1996). Identification of Saccharomonospora strains by the use of genomic DNA fragments and rRNA gene probes. Int J Syst Bacteriol 46, 502-505.

Yoon, J.-H., Lee, S. T. \& Park, Y.-H. (1998). Inter- and intraspecific phylogenetic analysis of the genus Nocardioides and related taxa based on $16 \mathrm{~S}$ rRNA sequences. Int $J$ Syst Bacteriol 48, 187-194.

Yoon, J.-H., Lee, K.-C., Kang, S.-S., Kho, Y. H., Kang, K. H. \& Park, Y.-H. (2000). Janibacter terrae sp. nov., a bacterium isolated from soil around a wastewater treatment plant. Int J Syst Evol Microbiol 50, $1821-1827$. 
Yoon, J.-H., Kang, K. H. \& Park, Y.-H. (2003). Psychrobacter jeotgali sp. nov., isolated from jeotgal, a traditional Korean fermented seafood. Int J Syst Evol Microbiol 53, 449-454.

Yoon, J.-H., Lee, H. B., Yeo, S. H. \& Choi, J. E. (2004). Janibacter melonis sp. nov., isolated from abnormally spoiled oriental melon in Korea. Int J Syst Evol Microbiol 54, 1975-1980.
Yurkov, V., Stackebrandt, E., Holmes, A. \& 7 other authors (1994). Phylogenetic positions of novel aerobic, bacteriochlorophyll $a$ containing bacteria and description of Roseococcus thiosulfatophilus gen. nov., sp. nov., Erythromicrobium ramosum gen. nov., sp. nov., and Erythrobacter litoralis sp. nov. Int J Syst Bacteriol 44, 427-434. 